\title{
Human Capital as an Object of Accounting in the Knowledge Economy
}

\author{
O. Kogut, ${ }^{1, *}$ \\ *Corresponding author: kogut.1108@gmail.com. \\ ${ }^{1} \mathrm{Al}$-Farabi Kazakh National University, Almaty, Kazakhstan
}

\begin{abstract}
The modern economy is called the economy of effective human capital, which emphasizes its main role in the development of the economy and society as a productive factor. Human capital is becoming the most important factor in the country's economic growth, the foundation of sustainable economic development. The article considers approaches to the definition of the concept and theoretical content of the category of human capital, its importance for the development of areas of science and practice. It is revealed that human capital is a necessary independent factor determining economic growth. The necessity of reflecting human capital in the system of accounting and reporting of firms is substantiated. The main problems of recognition of this most important factor of production are revealed, the directions of their further solution are determined. The scientific and practical necessity of introducing a new object of accounting and analysis of human capital is substantiated. The article contains information and conclusions that are of practical interest to firms.
\end{abstract}

Keywords: human capital, intangible asset, investments, accounting, financial statements.

\section{Introduction}

Throughout almost the entire history of mankind, until the beginning of the 1960s, the main role in the production process was played by physical capital: means of production, material conditions, etc. The requirements for labor were minimal: it was enough to have a muscular, "animal", natural force, which was used as one of the resources, as well as an appendage to technology. The creative abilities of man have not yet played a decisive role in economic development, and the problems related to the formation of labor did not cause much interest among economists.

It was traditionally believed that the labor market has an unlimited supply of workers. If there is a shortage of them in any of the sectors of the economy, it is enough to increase wage rates in it. This will ensure the overflow of labor from other sectors and thereby obtain the required number of workers of any skill level. In the world, the trend was gaining strength, within which the winner in the XXI century. it turns out to be not the one who has more natural resources or basic production assets, but the one who has higher quality of human capital. Therefore, the main strategic directions of the long-term development of Kazakhstan until 2050 is the development of human capital.

Unlike the means of production, human capital is not the property of the company. Human capital is embodied in the identity of its owner. The peculiarity of human capital is that it is inseparable from the person himself. Human capital cannot be the subject of sale, it can only be leased by entering into a contract of employment - an employment contract. For the period of employment, the employer acquires the right to take advantage of the opportunity to work as an employee, and not the labor itself, the owner of which is still the employee. Therefore, when developing plans for the strategic development of the company, it is necessary to keep in mind the structure and value of investments in human capital. From the position of the company, investments in human capital represent the costs that it incurs for the purpose of searching, selecting and training personnel, as well as their subsequent professional retraining.

However, in modern accounting practice, human capital is not taken into account in the company's balance sheet. Disputes surrounding the recognition and measurement of human capital as an asset are based on a subjective interpretation of the traditional foundations of accounting theory, not taking into account the main thing - business needs, which historically predetermined the development of accounting practices. Against this background, there is an underestimation of the human factor in the activities of modern firms, including an underestimation of the need to create transparent accounting and analytical support in relation to human potential. From the point of view of developing the theoretical foundations of accounting and analysis of human capital, this explains the interest in the human factor and the results of its intellectual work.

\section{Problem Statement}

The task of setting up this study is to consider the effectiveness of the use and development of human capital in modern conditions, in the accounting and information support of accounting for human capital management and the creation of an appropriate financial reporting system in the organization. The approaches to the classification of existing methods in Kazakhstan and foreign practice for assessing human capital will be considered. The main classification criteria will be determined by the economic level and the purpose of assessing human capital. 


\section{Research Questions}

The main research question is the development of practical solutions to the problems of accounting for human capital as part of the implementation of the long-term socio-economic development strategy of Kazakhstan. The purpose of the study is to consider approaches to determining the concept and theoretical content of the category of human capital, its importance for the development of areas of science and practice based on the knowledge economy.

\section{Materials and Methods}

In the study of human capital and the problems of its accounting, the article used the fundamental works of classics of economic and philosophical thought, monographs, scientific papers, articles of domestic and foreign scientists on the analysis of human capital as a source and basis for increasing and effective activity in the economy. Achieving the goal was based on the methods of neoclassical and institutional economic theory, system analysis, the laws of dialectical development of economic systems, general scientific methods of cognition: analysis and synthesis, induction and deduction; scientific abstraction and concretization, expert assessments, sociological surveys, comparative and socioinstitutional analysis.

\section{Results and Reasoning}

The theory of human capital was created by Nobel Prize winners in economics T. Schulz (1979) and G. Becker (1992). They calculated for the first time showed the advantages of people with special education over people with higher education in terms of income and increased education costs by the level of productivity investments, and education itself by the level of the most important development factor [1].

In the economic literature you can find many definitions of the concept of "human capital". The most common definitions: G. Becker "Human capital is a combination of innate abilities and acquired knowledge, skills and motivations, the effective use of which helps to increase income and other benefits" [1]; A. Dobrynin, S. Dyatlov, E. Tsyrenova "Human capital is a stock of health, knowledge and skills that contribute to the growth of labor productivity and affect income growth" [2]; V. Maksimovich V. "Human capital is a combination of available, accumulated and developed human abilities and qualities that are used in the production and consumption of economic goods, bring profit to its owner, as well as the effect at the place of use and contribute to the growth of the state" [3].

E. Flamholtz, the founder of the concept of accounting for human resources, believed that human capital is the most valuable tool of the company and should be taken into account as an asset of the company. Accounting for human resources is essential in making strategic decisions. He identified three main criteria for recognizing human capital as an asset: potential future economic benefits, ownership or control rights of an entity, and measurability in monetary terms [4].

J. Fitz-enz considered human capital as an asset, a powerful financial lever, the organization's most valuable and productive resource [5]. M. Arm-Strong in his definition of the concept of human capital spoke of him as a key element of the market value of the organization. In his opinion, "its price should be included in the calculation as an indicator for investors or those considering the possibility of a merger or acquisition of an organization" [6, p.848]. R. Likert, who was involved in the theory of human capital management ", also proposed introducing the article" Personnel investments "into the balance sheet as a company asset and reflecting these investments as an asset of the company" [7].

According to T. Schulz, "education is one of the forms of capital, it is called human because this form becomes part of a person, and capital is due to the fact that it is a source of future satisfaction or future earnings, or both." Later, T. Schulz supplemented his theory as follows: "Consider all human abilities either as innate or as acquired properties ... that are valuable and that can be developed with appropriate investments, will be human capital" [8, p.82].

The main characteristic features of human capital as part of human resources and as an object of accounting are the following [9]:

- the dependence of the functioning of human capital on the life expectancy of its carrier;

- the possibility of transforming the potential of human capital into specific scientific and technological developments;

- in many ways, the desire of human capital to integrate with production as confirming its innovative character;

- dependence of human capital on physical and moral depreciation;

- the complexity of calculating the economic benefits of investing in human capital until the actual income.

Traditional accounting science and practice do not consider human capital as an object of accounting, therefore this universally recognized economic category is not subject to registration in the system of accounting accounts and disclosure in financial statements. The main argument of OS Yasinskaya believes that the company does not have ownership of the carrier of human human capital, and traditional accounting does not recognize assets and does not reflect resources in accounting registers if ownership does not apply to them [10]. This is also noted by American economists L. Edwinsson and M. Melone, that the basis of the so-called knowledge economy is huge investments in human capital and information technology, but they do not find a positive reflection in the framework of traditional accounting [11, p.164]. 
Hence, at present, the idea of recognizing human capital as an asset of a firm seems problematic. Among the most significant arguments against the recognition of human capital as an asset, there is a lack of ownership of the use or possession of it.

Property as an economic category is manifested in the form of relations between people over various means, products of production, material goods through unhindered use, possession and disposal. As an economic category, this is not the means of production or their products per se, not the attitude of an individual person or group of people to the means of production and their products, but the relationship between people about the means of production and the material goods they produce.

Economic ownership requires ownership of the economic benefits of using an asset in one's business, rather than physical ownership. "Assets," noted B. Needles, H. Anderson, and D. Cowell, "are potential revenues that are possible as a result of the use by this legal entity of acquired or controlled values received by the organization as a result of previous transactions or past events" [12, p.496].

In the practice of international accounting, determining the presence of an asset for the right of ownership is not dominant. Most of the assets of the company are present under the financial control of the company when the assets are managed not on the basis of legal ownership, but in terms of ownership of the economic benefits received. According to Ya.V. Sokolova ".. if there is a contradiction between the legal and economic interpretation of the fact of economic life, the accountant should choose an economic interpretation of the fact of economic life" [13, p. 62 - 67]. This position is consistent with the accounting principle "priority of content over form", according to which transactions and other events should be reflected in accordance with their economic reality, and not just their legal form.

This approach is implemented in IAS 17 "Leases", according to which the leased asset acquired under financial leasing rights is reflected on the balance sheet of the lessee [17]. At the same time, an entity acquires financial benefits from the use of a leased asset for most of its economic life. Moreover, in order to objectively reflect the level of economic resources and liabilities, financial leasing in the lessee's balance sheet should be reflected as an obligation to pay rental payments in the future.

International financial reporting standards treat assets as organization-controlled resources from which the firm expects economic benefits in the future. Attributes of an asset [14]:

a) the asset brings economic benefits. Labor is a factor of production, allowing the employer to produce and sell products (work, services) produced by workers. The company has the opportunity to receive future economic benefits from the use of human capital as an asset throughout the term of the employment contract;

b) the presence of control over the asset. The organization's acquisition of labor carries the hiring process, is formalized in an employment contract and a work order. The firm has authority over human capital as an asset and has the ability to influence revenue through the exercise of its authority. The employer has the right to make requirements for the level of education, work experience, work experience in the specialty and other requirements. The date of commencement of work, place of work, mode of working time and rest time, size and procedure for the payment of wages are established. The employer entrusts the employee with a specific job, monitors its implementation, in case of non-fulfillment, brings the employee to disciplinary action. Thus, the employer controls human capital;

c) asset valuation. At the stage when labor activity has not yet begun, a person directs his efforts to getting upbringing and education. In order to adapt to the constantly changing conditions of the labor process, the employee repeatedly increases qualifications, improves skills. Assessment of human capital is a monetary expression of the accumulated knowledge of the skills of the individual to obtain generalized data on the organization in the preparation of financial statements.

If human capital is able to bring economic benefits in the future, then the company has full control, and the initial cost is determined, then it can be considered as an asset and can be allocated as an object of accounting. The study of human capital as an accounting category in business management allows you to pay due attention to the development of concepts of accounting and analysis of the company, to use the hidden potentials of intangible resources.

Human capital is attributed to intangible assets, which does not have a physical form, but at the same time has a certain value for the company. Human capital is transformed into company assets. Human capital is not interchangeable. In the company, individual human capital forms a corporate culture, environment. Human capital is inherent in people and cannot be owned by the company.

Intangible assets are currently a problem in the accounting methodology for both Kazakhstan and foreign companies, which is primarily due to the complexity of the subject itself, the definition of criteria for the classification and recognition of intangible assets. If you turn to IAS 38 "Intangible Assets" [17] and a number of provisions of IFRS 3 "Business Combinations" [18], IFRS 36 "Impairment of Assets" [19] and others, you can see that the international approach to the definition of intangible assets is based on a list of criteria for their identification from the rest of the assets, based on asset forms and research objectives.

However, human capital in the conditions of development of innovations, having become, undoubtedly, the main economic resource, should be provided with the accounting methodology and the methodology of its accounting assessment, methods of transformation of accounting results in financial statements. The complexity of updating the theory of accounting for human capital is enhanced by the fact that not only the path to the formation of human capital as a carrier of knowledge is long, but also the process of its transformation into technological innovations. It is human potential, in contrast to other forms of assets, that is distinguished by the property that its creation takes a long time and is based on human mental activity, which personifies the time and resources spent, but which is difficult to account for and evaluate in the subject's information system [15]. 
The American Association of Accountants determines that, "the process of accounting for human capital consists in identifying, measuring, and transmitting information to interested parties" [16, p. $170-174]$. The need for accounting and analysis of human capital for a company is determined by the fact that people are value, as they provide services and produce material values that can be quantified. However, this value of people cannot be owned by anyone, unlike other types of assets. The company cannot assign it. In addition, this value of the employee, as a production resource, largely depends on how relations between employees are formed in the company and how the production process is organized. Relations between workers are not taken into account by the classical microeconomic theory. He was ignored by the traditional accounting and analytical practice of economic activity. In the discussion of the qualitative and quantitative presentation of information in the annual reports of the company, the question of how appropriate and to what extent to present information in the financial statements of human capital, which, in essence, is capital in the form of intellectual abilities and practical skills acquired in the process, will be relevant education and implementation of human activities [16].

The only regulatory document for accounting for intangible assets is IAS 38 "Intangible Assets" [17]. But the international standard does not contain special emphasis on reporting such an indicator as human capital. Therefore, there is a need to develop new classification items for account 2700 "Intangible assets". As one of the options, we recommend the following scheme: to account 2700 open a sub-account 2701 "The right to use the knowledge and skills of employees" (analytical accounting is organized for each employee).

At the same time, personnel information can be presented in non-financial reporting. According to IFRS 1 "Presentation of financial statements", a company may provide additional information accompanying the annual financial statements if the governing body considers it useful and reliable for interested users of these statements when making the right economic and managerial decisions [20]. In modern conditions, such additional information may be information about human capital.

\section{Conclusion}

Functioning like physical capital, human capital has some fundamental differences, the main one of which is its inseparability from the face of its carrier. As a result, the market only sets prices for the "rent" of human capital (in the form of wage rates), while prices for its assets are absent. This seriously complicates the analysis. Secondly, human capital is able to increase the efficiency of activities both in the market and non-market sectors of the economy. Moreover, income from it can take both monetary and non-monetary forms. Human capital is the most important moment in the formation of a modern innovation environment. However, this object of economic reality is not reflected in the traditional accounting system. Therefore, not all facts of modern economic life are subject to registration, which violates the principle of objectivity.

There is an urgent need to take into account human capital in accounting, reflecting investments in this asset, and also analyze their effectiveness. The emergence of a new facility requires changes and additions to the standard Chart of Accounts and the development of methods for reflecting in the accounting of business transactions related to investing in human capital.

\section{References}

1. Yu.A. Korchagin, Development prospects for Russia. Human capital and innovative economy (CIRE, Voronezh, 2012). URL: http://www.lerc.ru/?part=articles\&art=25\&page=14,.- page=14. Accessed: 01.09.2019.

2. A.I. Dobryinin, S.A. Dyatlov, E.D. Tsyirenova, Human capital in the transitive economy: Formation, evaluation, efficiency of use (Science, Sankt Petersburg, 1999). [in Rus.].

3. A.A. Krugovaya, M.M. Pankova, Accounting and evaluation of the effectiveness of investments in human capital. Problems of Material Culture - Economic Science, 35-38 (2013). URL: http://dspace.nbuv.gov.ua/bitstream/handle/123456789/92335/09-Krugovaia.pdf?sequence=1. Accessed: 04.09.2019. [in Rus.].

4. E.G. Flamholtz, Human resource accounting: Advances in concepts, methods and applications (Springer, Boston, MA, 1999).

5. Ya. Fitts-ents, Profitability of investments into personnel: Measuring the economic value of personnel (Vershina, Moscow, 2006). [in Rus.].

6. M. Armstrong, Practice of human resources management, 10 edition (Piter, St. Petersburg, 2010). [in Rus.].

7. A.A. Kulikov, Human resources as a registration category. Siberian Financial School, 1, 64-67 (2007). [in Rus.].

8. A.G. Mokronosov, Y.V. Krutin, Human capital or human potential. Ideas and Ideals, 2(32/2), 80-89 (2017). DOI: 10.17212/2075-0862-2017-2.2-80-89. [in Rus.].

9. M.A. Kuznetsova, Cost approach to human resources management in the innovation economy. Fundamental Research, 2(3), 578-582. [in Rus.].

10. O.S. Yasinskaya, Theoretical justification of economic essence of human capital as a new object of accounting and analysis, Bulletin of Polotsk State University, Series "Economic and Legal Sciences", 5, 112-118 (2015). [in Rus.]. 
11. L. Edvinsson, M.S. Malone, Intellectual capital: Realizing your company's true value by finding its hidden brainpower (Harper Business, New York, 1997).

12. B.E. Needles, H.R. Anderson, J.C. Caldwell, Principles of accounting (Finance and statistics, Moscow, 2004). [in Rus.].

13. Ya.V. Sokolov, Fundamentals of accounting theory (Finance and statistics, Moscow, 2003). [in Rus.].

14. T.N. Obushenko, Accounting human capital, Science of Science, 8(3), 11-12 (2016). [in Rus.].

15. R.S. Kaplan, D.P. Norton, Balanced system of indicators, from strategy to action (Olimp-Biznes, Moscow, 2016). [in Rus.].

16. O.A. Kuzmenko, N.A. Masyuk, Human capital as object of accounting and reporting, Economics and Law Issues, 12, 170-174 (2013).

17. IAS 38 "Intangible Assets" (2004). URL: https://www.iasplus.com/en/standards/ias/ias38. Accessed: 01.09.2019.

18. IFRS 3 "Business Combinations" (2008). URL: https://www.iasplus.com/en/standards/ifrs/ifrs3. Accessed: 01.09.2019.

19. IFRS 36 "Impairment of Assets" (2017). URL: https://www.ifrs.org/issued-standards/list-of-standards/ias-36impairment-of-assets/. Accessed: 01.09.2019.

20. IFRS 1 "Presentation of financial statements" (2017). URL: https://www.ifrs.org/issued-standards/list-ofstandards/ias-1-presentation-of-financial-statements/. Accessed: 01.09.2019. 